\title{
INVESTIGATING PRESERVICE SECONDARY MATHEMATICS TEACHERS' PEDAGOGICAL CONTENT KNOWLEDGE: A CASE STUDY IN MICROTEACHING COURSE
}

\author{
Veronika Fitri Rianasari \\ Dosen Pendidikan Matematika, FKIP, Universitas Sanata Dharma \\ Alamat korespondensi: Kampus III Paingan, Maguwoharjo, Yogyakarta \\ E-mail: veronikafitri@usd.ac.id
}

\begin{abstract}
ABSTRAK
Guru yang efektif memiliki pengetahuan yang mendalam tentang konten materi pelajaran yang mereka ajarkan. Selain pengetahuan yang mendalam tentang materi yang diajarkan, guru juga harus memiliki pengetahuan yang mendalam tentang proses dan praktik belajar dan mengajar. Pengetahuan konten pedagogi adalah perpaduan pengetahuan disiplin ilmu atau materi ajar tertentu dan pengetahuan pedagogi. Tujuan dari penelitian ini adalah untuk menyelidiki Pedagogical Content Knowledge (PCK) 6 calon guru matematika di pembelajaran mikro. Data dikumpulkan dalam bentuk pengamatan, kuesioner dan dokumen tertulis. Selama microteaching, peneliti mengamati pemahaman preservice guru komponen PCK. Lembar observasi dirancang berdasarkan kerangka konseptual untuk menganalisis PCK yang dikembangkan oleh Chick, Baker, Pham, dan Cheng (2006). Temuan menunjukkan bahwa banyak siswa telah mengembangkan PCK mereka.amun masih banyak juga keterampilan dan pengetahuan yang harus ditingkatkan.
\end{abstract}

Kata kunci: PCK, pembelajaran mikro, calon guru matematika sekolah menengah.

\begin{abstract}
Effective teachers have a deep knowledge about the content of the subject matter they teach. As well as a deep knowledge of the material being taught, teachers must also have a deep knowledge about the processes and practices of teaching and learning. Pedagogical content knowledge is the intersection of discipline specific subject content knowledge and pedagogical knowledge. The purpose of this study is to examine Pedagogical Content Knowledge (PCK) of 30 preservice secondary mathematics teachers in microteaching course. The participants of this research are third-year preservice secondary mathematics teachers at Sanata Dharma University undertaking microteaching course. The data were collected in the form of observation, quesstionare, and written document. During the microteaching course, researcher observed preservice teachers' comprehension of PCK components. The observation sheet is designed based on the conceptual framework for analysing PCK developed by Chick, Baker, Pham, and Cheng (2006). The findings revealed that many students have developed their PCK. However there were also some skills and knowledge that should be improved.
\end{abstract}

Keywords: preservice secondary mathematics teachers, PCK, microteaching 


\section{Introduction}

\section{Background of the research}

The major goal of teacher education programs is to help preservice teachers improve their knowledge of and skills for effective teaching through coursework and practice. Mathematics teacher education programs heavily provide mathematical content and general pedagogy courses to support the development of preservice teachers' subject-matter and pedagogical knowledge. However, teachers not only need to possess knowledge of subjectmatter and pedagogy but also knowledge of curriculum, students, instructional tools, and assessment and be able to interweave them effectively (Shulman, 1986). Teaching practice program is conceived as an arena for preservice teachers to develop their ability of interweaving all types of knowledge for effective teaching. In such courses, preservice teachers discuss whether a particular topic is difficult or easy for students, what learning goals are defined for that topic in the curriculum, what teaching strategies and instructional tools facilitate students' learning and understanding, how to tailor the instruction to address the needs' of the students and how to assess students' understanding (Killic, 2010).
In Indonesia, in order to provide additional experience before the teaching practice program, preservice teachers should take microteaching course. Microteaching was invented in the middle of 1960 s and has been used to prepare teacher candidates to the real classroom setting. Most of microteaching practices in Indonesia are carried out in artificial classroom environment known also as laboratory environment. Microteaching practices carried out by preservice teachers will create an opportunity for them to use their theoretical content knowledge and pedagogical knowledge in classroom environment (Kartal, Ozturk,\& Ekici, 2012). Therefore preservice teachers should develop and articulate, what Shulman (1986) called, their pedagogical content knowledge (PCK).

\section{Theoretical Framework}

\section{Pedagogical Content Knowledge (PCK)}

Shulman (1986, 1987) classified teachers' knowledge into content knowledge, pedagogical knowledge, and pedagogical content knowledge. Shulman (1986) explained that PCK conceptualize 'the ways of representing and formulating the subject that makes it comprehensible to others' (p. 9). Later, in 1987, Shulman rephrased the defintion of PCK as a 'special amalgam of content and pedagogy 
that is uniquely the province of teachers, their own special form of prefessional understanding' (p. 8). PCK is an essential area of teacher development in higher level teaching (Shulman, 1987).

Cochran (1991) defined PCK as follows

Pedagogical content knowledge is an integrated understanding that is synthesized from teacher knowledge of pedagogy, subject matter content, student characteristics, and the environmental context of learning. In other words, PCK is using the understandings of subject matter concepts, learning processes, and strategies for teaching the specific content of a discipline in a way that enables students to construct their own knowledge effectively in an given context (p.11).

Chick, Baker, Pham, and Cheng (2006) proposed a framework for investigating PCK, and applied it to the content domain of decimal numbers. On the other hand See (2013) had conducted a research to examine teachers' PCK in three domains of PCK which are subject matter knowledge (SMK), general pedagogical knowledge (GPK) and knowledge of context (KOC). SMK is similar to subject content knowledge, GPK refers to the broad principles and strategies of classroom management and $\mathrm{KOC}$ means that teachers know how to address the learning needs of students according to their cognitive differences, social, cultural, and language background.

\section{Microteaching}

Microteaching course is a course in which the prospective teachers for the first time learn to manage learning in a structured way. This course is a preparation for practice teaching program in schools. Based on Microteaching Handbook of Sanata Dharma University (2013), student teachers are expected to master some basic teaching by applying the specific approach/learning model through microteaching courses. Some basic skills that must be mastered by students are opening and closing skills lessons, asking questions and giving reinforcement, explaining and giving varying stimulus. Microteaching is a "real teaching" but it is not a "real classroom teaching", therefore, prospective teachers are expected to do a lot of teaching practice and they are required to be able to put the experience into practice in a comprehensive manner in a real classroom teaching.

Allen and Ryan in Benton-Kupper (2001) stated that microteaching is "a training concept that can be applied at various pre-service and in-service stages 
in the profesional development of teachers." During microteaching, teachers have opportunities to practice in an instructional setting in which the normal complexities of the classroom are limited and in which they can receive feedback on their performances. Magnusson, Krajacik, \& Borko (1999) pointed out that having teaching experience is an important factor for the development of pedagogical content knowledge. Pedagogical content knowledge develops along with teaching experience.

\section{METHODOLOGY}

This study employed the qualitative case study methodology. Qualitative case study methodology was chosen because it provides tools for researcher to study complex phenomena within its contexts using variety of data sources (Baxter \& Jack, 2008).

This study investigated secondary preservice mathematics teachers' Pedagogical Content Knowledge in microteaching course. The participants of this research are third-year preservice secondary mathematics teachers at Sanata Dharma University undertaking microteaching course.

During the microteaching course, researcher observed six preservice teachers' comprehension of PCK components. This selection was based on the consideration of teachers' academic ability. Two teachers have high academic ability, two teachers have medium academic ability, and two teachers have low academic ability. At the end of the course, researcher assessed all preservice teachers' PCK in three domains of PCK. The instruments used in this research are questionnaire and observation sheet. The observation sheet is designed based on the conceptual framework for analysing PCK developed by Chick, Baker, Pham, and Cheng (2006). Meanwhile, the questionnaire is addressed to guide the students to reflect on their microteaching experiences towards three domains of PCK designed based on the framework developed by See (2013).

\section{RESEARCH FINDINGS AND DISCUSSION}

Below is the description of six preservice teachers' performance analysed based on the framework developed by Chick, Baker, Pham, and Cheng (2006).

\section{Teaching Strategies}

In practicing learning process, all teachers used some teaching strategies such as making relationship between mathematical concepts to real life, organising games, and engaging students to participate in learning process by posing problems. Only two teachers showed some specific strategies related to 
a certain mathematics concepts, including making connections between two related concepts (sine and cosine rule) and approximating the area of curvilinear regions to introduce integral concept.

\section{Students Thinking}

Since microteaching is not a real classroom teaching, therefore there is not enough evidence that show teachers' effort to discuss or respond to possible student ways of thinking about a concept, or recognize typical levels of understanding. Most of the teachers assumed that all students can think in a formal way particularly in understanding formulas or theorems. In doing discussion, the teachers did not accommodate different variety of students' understanding. Moreover, teachers did not stressed or addressed typical student misconceptions about a concept. Teachers focused on what they have planned, which are learning goals written in their lesson plan.

\section{Cognitive Demand of Task}

Four teachers only gave routine problems to their students. Therefore, it was not clearly shown their ability to identify aspects of the task that affect its complexity. However, there are two teachers who gave some problems with varying levels of difficulty so that they can identify aspects of the task that affect its complexity.

\section{Representations of Concepts}

Teachers did not provide many ways to illustrate a mathematics concept. Teachers tended to directly use formal symbols and most of the teacher only used picture or two dimensional figure to illustrate a concept. For example, there was a teacher who used rectangles to determine the area under a curve to illustrate the concept o definite integral.

\section{Knowledge of Resources}

The types of learning resources used by teachers in the learning process are very limited. All teachers only used one book source that is high school mathematics textbook. Two teachers engaged students to explore various sources as references to solve problems. Two other teachers use mathematics software, that is GeoGebra, to explore the properties of vector and definite integral.

\section{Curriculum Knowledge}

None of the teachers explained how a certain mathematics concept fit into the curriculum. In the beginning of a lesson, teachers only mentioned the learning goals and they did not explain the link between a mathematics concepts and curriculum.

Profound Understanding of Fundamental Mathematics 
Only two teachers showed deep and thorough conceptual understanding of identified aspects of mathematics. The other teachers failed to demonstrate a deep understanding of a concept. It can be seen from their explanation which is very superficial, limited to the application of a formula (how to solve a problem), less in the explanation of why a certain method works in solving a problem.

\section{Deconstructing Content to key Components}

From teachers' lesson plan, it can be shown that most of the teachers showed their ability to indentify keys components that are fundamental for understanding and applying a concept in the subject they teach. However, this identification was not clearly shown in learning process. Since teachers tended to focus on procedural knowledge, they did not stressed on the key components. Only one teacher clearly deconstructed content (integral content) to key components.

\section{Mathematical Structure and Connections}

Two teachers did not explain the relationship among concepts or between concepts and topics. For example, the teacher did not explain the relationship between the concept of vectors with the operations on vectors, why there are operations on vector. While, the other teachers pointed among concepts or between concepts and topics. For example, the teacher explain the relationship between the rules of law of sines and cosines with the area of a triangle.

\section{Procedural Knowledge and Methods of Solution}

All teachers have good skill in solving mathematical problems. However, three teachers only provide routine problems. The other teachers not only provide routine problems, but also non routine problems. However, only two teachers used various methods of solutions that reflect her deep understanding of the topic.

\section{Goals for Learning}

All of the teachers explicitly mentioned the learning goals related to specific mathematics content in the beginning of learning. Only two teachers mentioned the learning goals that are not directly related to content, for example: teachers related mathematics content to critical thinking ability. However, it was an interesting phenomenon about explaning learning goals explicitly in the beginning of learning process. By mentioning the learning goals, students know what they are going to learn. However, the explanation of learning goals might inhibit students to reach their fullest potential. 
Instead of telling the learning goals explicitly, teachers can pose essential questions or activities that can support students to construct their own meaning through a variety of activities.

\section{Getting and Maintaining Student Focus}

There are some strategies used by the teachers to get and mantain students focus. All of the teachers posed questions to the students and showing pictures/videos in real life that show the application of the concepts in real life. Three teachers used games to attrack students' attention, and two teachers used mathematics software to illustrate mathematics concepts.

Based on the questionnaire, the table below shows reflection of 26 students on three domains of PCK in the end of microteaching course.

Table 2. Data of students' reflection on three domains of PCK

\begin{tabular}{|c|c|c|c|c|c|c|}
\hline \multirow[t]{2}{*}{$\begin{array}{l}\text { Domains of } \\
\text { PCK }\end{array}$} & \multicolumn{5}{|c|}{$\begin{array}{c}\text { Percentage of students based on the } \\
\text { criteria } * \text { ) }\end{array}$} & \multirow[t]{2}{*}{$\begin{array}{l}\text { General } \\
\text { Criteria }\end{array}$} \\
\hline & $\overline{V G}$ & $\mathbf{G}$ & $\mathbf{F}$ & $\overline{\mathbf{P}}$ & VP & \\
\hline $\begin{array}{c}\text { Subject } \\
\text { Matter } \\
\text { Knowlegde }\end{array}$ & $47.6 \% \%$ & $47.6 \%$ & $4.8 \%$ & - & - & VG \\
\hline $\begin{array}{c}\text { General } \\
\text { Pedagogical } \\
\text { Knowledge }\end{array}$ & $71.4 \%$ & $28.6 \%$ & - & - & - & VG \\
\hline $\begin{array}{c}\text { Konwledge } \\
\text { of Context }\end{array}$ & 52.4 & $47.6 \%$ & - & - & - & VG \\
\hline
\end{tabular}

*)Desription: VG: Very ; G: Good ; M: Fair ; P: Poor ; VP: Very Poor

The table above show that all preservice teachers have very good criteria in three domains of PCK, including subject matter knowledge, general pedagogical knowledge, and knowledge of context. However, the result and analysis of six preservice teachers' performance in practicing learning process showed that there are many skills and knowledge that should be improved in order to be able to conduct an effective learning process.
This result indicates two things. First, the preservice teachers had already had good quality in subject matter knowledge, general pedagogical knowledge, and knowledge of context, but they did not able to blend it in conducting teaching and learning process. Second, the preservice teachers do not realize that their ability or knowledge was not optimal and it should be improved to carry out effective learning. They might think that their 
ability or knowledge in teaching mathematics was good enough.

\section{CONCLUSION}

Based on the analysis, it can be concluded that prospective teachers' $\mathrm{PCK}$ in three categories, those are 'clearly PCK', 'content knowledge in a pedagogical contenxt', and 'pedagogical knowledge in a content context', should need to be improved. Magnusson et al. (1999) argued that a teacher education program can never completely address all the components of PCK that a teacher need. On the other hand, since PCK is a specific form of knowledge for teaching which refers to the transformation of subjectmatter knowledge in the context of facilitating students' undertanding, then preservice teachers should master components of PCK and must have a lot of experience to teach mathematics both in microteaching or in real teaching in school since the major source of a teachers' PCK is teaching experience

\section{REFERENCES}

Appleton, K. 2008. Developing science pedagogical content knowledge through mentoring elementary teachers. Journal of Science Teacher Education,19(6), 523-545.

Baxter, P., \& Jack, S. 2008. Qualitative case study methodology: Study design and implementation for novice researchers. The qualitative report, 13(4), 544-559.

Benton-Kupper, J. (2001). The microteaching experience: Student perspectives. Education, 121(4), 830.

Briscoe, C., \& Peters, J. 1997. Teacher collaboration across and within schools: Supporting individual change in elementary science teaching. Science Teacher Education, 81(1), 51-64.

Carter, M. \& Francis, R. 2001. Mentoring and beginning teachers' workplace learning. Asia-Pacific Journal of Teacher Education, 29(3), 249-261

Cochran, K. F., King, R. A., \& De Ruiter, J. A. 1991. Pedagogical Content Knowledge: A Tentative Model for Teacher Preparation. Symposium paper presented at the annual meeting of the American Educational Research Association, Chicago.

Çontay, E. G., \& Paksu, A. D. 2012.

Preservice Mathematics Teachers'

Understandings of The Class

Inclusion Between Kite and

Square. Procedia-Social and

Behavioral Sciences, 55, 782-788. 
Fujita, T. 2012. Learners' level of understanding of the inclusion relations of quadrilaterals and prototype phenomenon. The Journal of Mathematical Behavior, 31(1), 60-72.

Hobson, A. J., Ashby, P., Malderez, A., \& Tomlinson, P. D. 2009. Mentoring beginning teachers: What we know and what we don't. Teaching and teacher education, 25(1), 207-216.

Hudson, P., \& Hudson, S. 2010. Mentor educators' understandings of mentoring preservice primary teachers. International Journal of Learning, 17(2), 157.

Kartal, T., Ozturk, N., \& Ekici, G. (2012). Developing pedagogical content knowledge in preservice science teachers through microteaching lesson study.Procedia-Social and Behavioral Sciences, 46, 2753-2758.

Kilic, H. (2010). The nature of preservice mathematics teachers' knowledge of students. Procedia-Social and Behavioral Sciences, 9, 1096-1100.

Magnusson, S., Krajcik, J., \& Borko, H. (1999). Nature, sources, and development of pedagogical content knowledge for science teaching.
InExamining pedagogical content knowledge (pp. 95-132). Springer Netherlands.

Miller, A. 2002. Mentoring studetns and youg people. Norfolk: Routledge

Rowland, T., Huckstep, P., \& Thwaites, A. 2005. Elementary teachers' mathematics subject knowledge: The knowledge quartet and the case of Naomi. Journal of Mathematics Teacher Education, 8(3), 255-281.

See, N.L.M. 2013. Mentoring and Developing Pedagogical Content Knowledge in Beginning Teachers. Procedia-Social and Behavioral Sciences, 9, 53-62

Shulman, L.S. 1986. Those who undersand: Knowledge growth in teaching, educational researcher, 15 (2), 4-14.

Shulman, L.S. 1987. Knowledge and teaching: Foundation of the new reform. Harvard Educational Review, 57 (1), 1-22 
